\title{
KEBIJAKAN KELAUTAN DALAM RANGKA MENJAGA DAN MENGELOLA SUMBER DAYA ALAM LAUT SEBAGAI UPAYA MEWUJUDKAN INDONESIA SEBAGAI POROS MARITIM DUNIA
}

\author{
Lathifah Hanim, Mohammad Shofii Noorman \\ Fakultas Hukum Universitas Islam Sultan Agung Semarang \\ Jl. Raya Kaligawe Km. 4 Semarang \\ E-mail: lathifah.hanim@yahoo.co.id; msnoorman43@gmail.com
}

\begin{abstract}
Indonesia has a vision World Maritime Poros. The government's agenda corresponds with the vision include the construction of a maritime culture, maritime resource management, infrastructure development and connectivity maritime, maritime security and defense diplomacy. Marine resources has great potential for the development of the national economy in order to realize Indonesia as the shaft maritime world, however, the setting and its use should be undertaken with caution in order to avoid destruction of the population, habitat and ecosystem. As a developing country, Indonesia must establish closer cooperation with technologically advanced countries to explore the marine resources. In addition, to realize the ideals of Indonesia as the World Maritime shaft must be able to ensure that safety and security in the sea area a top priority.
\end{abstract}

\section{Keywords: World Maritime Poros, Maritime Policy, Marine Resource Management}

\begin{abstract}
Abstrak
Indonesia memiliki visi sebagai Poros Maritim Dunia. Agenda pemerintah terkait dengan visi tersebut diantaranya adalah pembangunan budaya maritim, pengelolaan sumber daya maritim, pembangunan infrastruktur dan konektivitas maritim, diplomasi dan pertahanan keamanan maritim. Sumber daya kelautan memiliki potensi yang sangat besar untuk pengembangan ekonomi nasional dalam rangka mewujudkan cita-cita Indonesia sebagai poros maritim dunia, meskipun demikian pengaturan dan pemanfaatannya harus dilaksanakan secara seksama agar tidak terjadi kerusakan populasi, habitat dan ekosistem. Sebagai negara berkembang, secepatnya Indonesia menjalin dan memperkuat kerjasama bersama negara maju untuk pengembangan teknologi eksplorasi dan eksploitasi sumber daya laut. Selain itu, untuk mewujudkan cita Indonesia sebagai pusat dari maritime dunia, maka Indonesia harus memprioritaskan peningkatan keselamatan dan keamanan daerah laut.
\end{abstract}

Kata kunci: Poros Maritim Dunia, Kebijakan Kelautan, Pengelolaan Sumber Daya Laut

\section{A. PENDAHULUAN}

Saat ini adalah era baru bagi perekonomian dunia. Pembuatan kebijakan serta giat geliat perdagangan dunia di latarbelakangi oleh globalisasi. Organisasi-organisasi perdagangan 
dunia baik melalui WTO dan lainnya menjadi bumbu penyemangat. Semangat ini didasari dari pandangan dan pengalaman selama proses perdagangan dilakukan. Zero resistance menjadi paham yang sekarang dianut dan dikembangkan karena diyakini dapat meningkatkan volume perdagangan antar negara.

Seiring berubahnya tingkat produktifitas, berubah pula situasi arus perdagangan. Saat ini perdagangan dunia dipegang oleh negara China. Amerika dan Eropa yang dulu menguasai malah berubah dan saat ini berada di titik lesu perdagangan. Hal ini membuat arus perdagangan yang ada berubah dan meningkatkan volume perdagangan hingga $45 \%$ (empat puluh lima persen) dari total perdagangan laut dan itu menggunakan laut Indonesia. ${ }^{1}$

Era Masyarakat Ekonomi Asean (MEA) saat ini menjadi salah satu penyebab meningkatnya volume perdagangan dan produktifitas ekonomi. Dua hal tersebut diatas seharusnya dapat membuat Indonesia menteremahkan ini sebagai peluang dan upaya untuk memperkuat jati diri sebagai negara poros maritime dunia. ${ }^{2}$

Konsekuensi logis pilihan mejadi negara Poros Maritim Dunia bisa dicapai melalui upaya pengembalian identitas Indonesia sebagai bangsa maritim, pengamanan kepentingan dan keamanan maritim, pemberdayaan seluruh potensi maritim demi kemakmuran bangsa, pemerataan ekonomi Indonesia melalui tol laut, dan melaksanakan diplomasi maritim dalam politik luar negeri Indonesia selama jangka waktu lima tahun kedepan. Sehingga dapat dipahami, bahwa untuk menuju Negara Poros Maritim Dunia akan mencakup praktek dan proses pembangunan maritim di berbagai aspek, seperti politik, sosial-budaya, pertahanan dan keamanan, infrastruktur, terutama aspek ekonomi dan regulasinya.

Posisi strategis Negara Kesatuan Republik Indonesia diantara persilangan samudra Hindia dan samudra Pasifik secara otomatis memberikan banyak potensi sumber daya laut yang dapat dikelola dan dimanfaatkan untuk masa depan bangsa dan tulang punggung pembangunan nasional, namun pemanfaatan potensi Sumber Daya Laut (SDL) secara optimal haruslah diarahkan pada pendayagunaan sumber daya ikan dengan memperhatikan daya dukung yang ada dan kelestariannya guna meningkatkan kesejahteraan rakyat. Jumlah ikan di perairan Indonesia yang sangat melimpah jangan hanya menjadi tangkapan dan curian bagi kapal-kapal asing, namun justru diberikan kepada nelayan lokal untuk meningkatkan kesejahteraan penduduku di kawasn pesisir dan sekitarnya.

Secara geografis, Indonesia terletak pada $6^{\circ} \mathrm{LU}-11^{\circ} \mathrm{LS}$ dan antara $95^{\circ} \mathrm{BT}-141^{\circ} \mathrm{BT}$. Letak secara geografis tersebut merujuk pada letak berdasarkan garis lintang dan bujur. Jika berpedoman pada leak geografis tersebu, maka Indonesia menjadi Negara beriklim tropis, dengan curah hujan yang tinggi, menerima penyinaran matahari sepanjang tahun, dan banyak penguapan sehingga kelembapan udara tinggi. Sebagai negara tropis, seyogyanya sangat

1 Muhammad Jamil, Indonesia Poros Maritim Dunia Menuju Ekonomi Berbasis Kelautan, 2015, http://www.kompasiana.com/muhammad/indonesia-poros-maritim-dunia-menuju-ekonomi-berbasiskelautan_54f38221745513962b6c789b, (diakses pada 15/11/2016)

Ibid. 
banyak kekayaan sumber daya yang dimiliki oleh Indonesia, termasuk SDL sebagaimana telah disebutkan sebelumnya.

Berdasarkan latar belakang tersebut, penulis tertarik untuk menulis makalah ini dengan judul kebijakan kelautan dalam rangka menjaga dan mengelola sumber daya alam laut sebagai upaya mewujudkan Indonesia sebagai poros maritim dunia. Sedangkan permasalahan yang coba dijawab adalah berkaitan dengan bagaimanakah kebijakan kelautan dalam rangka menjaga dan mengelola sumber daya alam laut sebagai upaya mewujudkan Indonesia sebagai poros maritim dunia.

\section{B. PEMBAHASAN}

\section{Posisi Strategis Laut Indonesia}

Secara bahasa, merujuk pada pengertian menurut Bahasa Indonesia, laut diartikan sebagai kumpulan air asin dalam jumlah yang banyak dan luas yang menggenangi dan membagi daratan atas benua atau pulau. Jadi laut merupakan air yang menutupi permukaan tanah yang sangat luas dan umumnya mengandung garam dan berasa asin. Biasanya air mengalir yang ada di darat akan bermuara ke laut. ${ }^{3}$ Hampir seluruh negara d dunia memiliki wilayah laut, kecuali sebagian kecil saja yang tidak memiliki wilayah laut dan hanya berupa daratan.

Sedangkan definisi kelautan menurut Undang-Undang Nomor 32 Tahun 2014 adalah hal yang berhubungan dengan Laut dan/atau kegiatan di wilayah Laut yang meliputi dasar Laut dan tanah di bawahnya, kolom air dan permukaan Laut, termasuk wilayah pesisir dan pulaupulau. Untuk melindungi wilayah laut Indonesia, Pemerintah melakukan upaya pelindungan lingkungan Laut melalui konservasi Laut, pengendalian Pencemaran Laut, penanggulangan bencana Kelautan, dan pencegahan dan penanggulangan pencemaran, kerusakan dan bencana. Upaya-upaya tersebut dilakukan seiring dengan banyaknya kegiatan yang dapat mencemari wilayah laut Indonesia, seperti illegal fishing, pembuangan limbah cair ke laut kecelakaan kapal tanker pengangkut minyak di laut dan sebagainya.

Sebagaimana dijelaskan sebelumnya, pengaturan mengenai kelautan diatur dalam Undang-Undang Nomor 32 Tahun 2014 yang terdiri atas beberapa bab. Bab pertama mengatur tentang Ketentuan umum, kemudian bab kedua mengatur tentang asas dan tujuan, bab ketiga mengatur tentang ruang lingkup, bab keempat mengatur tentang wilayah laut, bab kelima mengatur tentang Pembangunan Kelautan, bab Keenam mengatur tentang Pengelolaan Kelautan, bab ketujuh mengatur tentang Pengembangan Kelautan, bab kedelapan mengatur tentang pengelolaan ruang laut dan pelindungan lingkungan laut, dan bab kesembilan atau bab terakhir mengatur tentang Pertahanan, keamanan, penegakan hukum, dan keselamatan di laut.

Banyaknya jumlah bab di undang-undang tersebut mengindikasikan bahwa wilayah laut perlu dikelola dan dilindungi secara maksimal dan menyeluruh. Sebab, pada dasarnya laut memiliki banyak fungsi / peran / manfaat bagi kehidupan manusia dan makhluk hidup lainnya

3 kbbi.web.id/laut diakses pada tgl. 20 Nopember 2016. 
karena di dalam dan di atas laut terdapat sangat banyak sekali kekayaan sumber daya alam yang dapat kita manfaatkan diantaranya yaitu : sebagai tempat rekreasi dan hiburan, sebagai pembangkit listrik tenaga ombak, pasang surut, angin, juga sebagai tempat budidaya ikan, kerang mutiara, rumput laut, dan sebagainya. Laut juga bisa diekplorasi sebagai tempat barang tambang berada, sebagai salah satu sumber air minum (desalinasi, proses ini banyak dimanfaatkan oleh negara maju untuk menjaga ketersediaan air bersih bagi masyarakat), sebagai jalur transportasi air, sebagai tempat cadangan air bumi dan sebagai objek riset penelitian dan pendidikan serta banyak lagi potensi laut.

Negara maritime terbesar di dunia adalah Indonesia. Mendapatkan predikat ini karena Indonesia memiliki 13.500 pulau dan wilayah laut dengan panjam 3.000mil. Indonesia berada di antara 2 (dua) samudera serta 2 (dua) benua dan ini mmbuat Indonesia berada di wilayah sangat strategis dari jalur perdagangan laut dunia.

$75 \%$ (tujuh puluh lima persen) wilayah Indonesia adalah perairan (laut) yang membuat Indonesia acapkali dilalui kapal berisikan barang produksi yang bernilai 45\% (empat puluh lima persen) jumlah perdagangan di dunia. Era MEA dan meningkatnya gairah perdagangan saat ini membuat Indonesia memiliki masa depan yang cerah karena potensi lautnya yang tinggi (baru ditilik dari sisi Indonesia sebagai jalur perdagangan dunia, belum sisi lain).

Hal tersebut adalah peluang bagi Indonesia. Seharusnya pemerintah dapat menjadikan wilayah laut sebagai prioritas kebijakan nasional. Untuk mendukung hal tersbeut tentu tetap ebrlandaskan pada konstitusi dimana konsisten mengutamakan integritas, kesejahteraan masyarakat dan politis luar negeri bebas aktif. Lebih dalam lagi, seluruh aktifitas tersbeut untuk menjaga keutuhan Indonesia.

Berbicara mengenai besarnya volume perekonomian, Indoensia dapat disejajarkan dengan India, Amerika, Cina, Eropa dan Brazil. Namun tidak serta merta treatment yang dilakukan sama mengingat secara geografis, Indonesia berbeda dengan negara-negara tersebut. Indonesia memiliki wilayah yang sebagian besar adalah laut sedangkan negara lainnya tidak. Ini menyebabkan membengkaknya biaya distribusi. Biaya mahal tersebut dikarenakan wilayah laut membatasi distribusi, kurang efektif dan efisien, sementara jika harus dikirim melalui udara, tentu biaya akan bertambah mahal lagi.

Keberadaan Indonesia sebagai negara maritime diwakili salah satunya oleh Kepulauan Riau. Kepulauan Riau memiliki posisi yang sangat strategis dan berada di jalur perdagangan Indonesia selama berates-ratus tahun. Ini membuat masyarakat Kepulauan Riau menjadi pedagang antar pulau. Walaupun ada yang memiliki pekerjaan lainnya, tetapi itu hanya sebagian kecil. Kepulauan Riau adalah barrier dan gerbang perdagnagan dunia karena posisi strategsinya di selat malaka, bagian barat nusantara. agian tenggara selat malaka tersebut merupakan pusat sumber komoditi perdagangan rempah-rempah dunia sejak abad ke-15 hingga abad ke-19. 
Wilayah Kepulauan Riau semakin mengkokohkan diri menjadi wiayah dengan penduduk sebagian besar pedagang karena para saudagar dari Cina, Melayu, India dan Arab menetap di saya. Mereka diceritakan sebagai orang laut yang selama ratusan tahun menjadikan nusantara sebagai jalur perdagangan Maka, potensi alami tersebut sejatinya bisa dimanfaatkan untuk mendukung upaya Indonesia sebagai poros maritim dunia.

\section{Potensi Ekonomi Kelautan}

Gambaran mengenail letak strategis Indonesia, terutama dengan wilayah lautnya, juga berdampak pada aspek perekonomian yang ada. Masyarakat Indonesia sebenarnya harus sejahtera mengingat potensi laut Indonesia yang besar dan memakmurkan. Zona Ekonomi Ekslusif Indonesia seluas $2.400 .000 \mathrm{~km} 2$ sangat kaya akan sumber daya laut dan dapat dimanfaatkan sebagai sarana mensejahterakan rakyat Indoneisa. ${ }^{4}$ Sayangnya Indonesia belum dapat memaksimalkan potensi ekonomi laut tersebut. Permasalahan kurang maksimalnya eksploitasi ini disebabkan Indonesia belum didukung oleh teknologi yang mumpuni.

Sebenarnya dengan zona ekonomi ekslusif yang luas, banyak factor yang dapat digali potensinya antara lain sector perikanan budidaya, sector pengolahan perikanan, eksplorasi dan eksploitasi sumber daya energi laut lepas, serta tentunya sector perikanan tangka. ${ }^{5}$ Beragam sekor tersebut faktanya saat ini belum banyak dieksplorasi sehingga membuka peluang besar bagi kapal-kapal asing untuk mengeruk kekayaan laut Indonesia secara illegal. Tertangkapnya kapal-kapal berbendera asing yang akhir-akhir ini kerap diberitakan oleh media, merupakan bukti bahwa kekayaan laut Indonesia sangat banyak dan belum bisa dimanfaatkan untuk peningkatan kesejahteraan masyarakat.

Banyak potensi yang dapat digali pada sumber daya laut Indonesia. Sebagai contoh, apabila menggali potensi ikan di laut Indonesia, nilai ekspor terhadap ikan seharusnya tinggi. Namun ini tidka terjadi karena faktor internal yaitu kurangnya daya konsumsi ikan di masyarakat Indonesia sendiri. Hal ini menyebabkan pasar domestik Indonesia terhadap ikan masih rendah. Dengan meningkatkan konsumsi ikan di masyarkaat Indonesia, diharapkan peningkatan terhadap pasar domestik dapat meningkatkan pula nilai eksporSelain itu juga, pemerintah dituntut untuk kreatif mengkampanyekan program gemar ikan, sebagaimana yang telah diinisiasi oleh Kementerian Kelautan. Dengan semakin sadarnya masyarakat tentang manfaat ikan laut, maka tingkat konsumsi ikan di pasar domestic juga akan meningkat.

Peranan sektor kelautan dan perikanan dalam pembangunan nasional terutama adalah mendorong pertumbuhan agro industri melalui penyediaan bahan baku, meningkatkan devisa melalui peningkatan ekspor hasil produk kelautan dan perikanan, meningkatkan kesempatan dan peluang terbukanya lapangan kerja, meningkatkan pendapatan dan kesejahteraan petani atau nelayan serta menunjang pembangunan nasional melalui pajak dari transaksi yang ada. Sejalan dengan itu, maka kebijakan umum pembangunan sektor kelautan dan perikanan harus

4 G. T. Suroso, Poros Maritim dan Perkembangan Perekonomian Indonesia, 2015, http://www.bppk.kemenkeu.go.id/publikasi/artikel/150-artikel-keuangan-umum/20555-poros-maritim-danperkembangan-perekonomian-indonesia, (diakses pada 14/11/2016). Ibid. 
berorientasi pada peningkatan produktivitas, nilai tambah, perluasan kesempatan kerja dan efisiensi usaha serta peningkatan pendapatan usaha sektor kelautan dan perikanan. Kebijakan tersebut harus terintegrasi dan melibatkan seluruh lapisan masyarakat, mensinergikan hulu hingga hilir dan memantau berjalannya program secara kontinyu.

Tridoyo Kusumastanto menyatakan ada 7 (tujuh) sektor kelautan yang memiliki hubungan erat dengan pembangunan ekonomi bangsa. Sector tersebut adalag pertambangan, perikanan, jasa kelautan, industri kelautan, pariwisata bahari, bangunan kelautan, dan perhubungan laut. Menurut perhitungan beliau, kelautan menyumbang sekira 22,5 persen dari produk domestik bruto (PDB). Hal tersebut membuat pemerintah, masyarakat dan pelahku usaha harus memberikan perhatian khusus terhadap sector-sektor tersebut.

Meskpiun demikian, ada beberapa masalah dan tantangan untuk dapat bangkit dan Berjaya dalam sector kelautan tersebut karena banyak permasalahan yang ada. Dapat dimulai dari identifikasi dan pemanfaatan SDL, manajemen birokarasi , revisi peraturan eprundangundangan, upaya meningkatkan investasi, dll. Identifikasi harus dilakukan untuk memudahkan pemerintah dan pemangku kebijakan guna menghasilkan solusi yang solutif dan relevan.

Pemerintah perlu melakukan usaha yang lebih signifikan dan masif guna menjadikan sektor kelautan sebagai tulang punggung pembangunan ekonomi bangsa Indonesia. Upaya ini misalnya Pertama, pengelolaan SDL dan perikanan berkelanjutan dan berbasis masyarakat. Pengelolaan ini berupa proses yang terintegrasi mulai dari pengumpulan informasi, analisis, perencanaan, konsultasi, pengambilan kesimpulan, alokasi sumber dan implementasinya menyangkut segenap potensi baik renewable maupun non renewable resource kelautan dan perikanan. Pengelolaan ini harus mengarah pada bagaimana SDL yang ada saat ini mampu memenuhi kebutuhan sekarang dan kebutuhan generasi yang akan datang, dimana aspek keberlanjutan harus meliputi aspek ekologi, ekonomi dan sosial.

Kedua, mendorong peningkatan nilai investasi kelautan dan perikanan dari penanaman modal dalam negeri. Hal ini dimaksudkan agar besarnya potensi SDL dan perikanan yang dimiliki bangsa ini dapat dinikmati oleh warganya sendiri. Selain itu pemerintah perlu untuk melakukan kajian lebih detail tentang usaha-usaha perikanan yang dapat dikembangkan di Indonesia di tahun-tahun yang akan datang. Hal ini penting dilakukan karena era milenial membutuhkan inovasi dan kreasi. Percepatan pertumbuhan ekonomi bisa dicapai melalui inovasi dan kreasi tersebut. Sebaliknya, suatu program akan terhenti ketika tiada invasi dan kreasi.

Ketiga, memperbaiki daya saing produk kelautan dan perikanan di pasar Internasional. Pemerintah, industri, akademisi dan masyarakat hendaknya dapat bekerjasama secara sinergis guna meningkatkan nilai daya saing produk tersebut. Pola kemitraan antara keempat elemen tersebut sangat berarti dalam mendorong kualitas produk kelautan dan perikanan. Selain itu perlu juga adanya program peningkatan Sumber Daya Manusia (SDM) berupa pelatihan, penyuluhan dan keterampilan yang lebih terpadu kepada masyarakat yang bekerja dan akan bekerja di sektor perikanan dan kelautan. 
Keempat, negara sesegera mungkin menyusun regulasi untuk dapat melakukan optimalisasi terhadap potensi perikanan dan kelautan. Regulasi tersebut hendapknya dapat menjadi problem solving untuk problematika perikanan dan kelutan Indonesia. Sebagai contoh, persoalan otonomi daerah dan desentralisasi serta sengketa mengenai wilayah terluar dan perbatasan dengan regulasi Apabila regulasi yang baik dan disosialisasikan kepada masyaraat, diharapkan dapat memacu pertumbuhan ekonomi di sektor kelautan dan perikanan.

Berbasis pada seluruh potensi dan tantangan yang dimiliki Indonesia sebagai konsekuensi dari reorientasi kebijakan pembangunan menuju pengembangan perekonomian maritim, maka paradigma pembangunan sektor kelautan dan perikanan-pun harus digeser menjadi prioritas pembangunan perekonomian. Upaya tersebut harus berorientasi pada wilayah maritim yang terintegrasi dengan pembangunan wilayah darat. Pembangunan maritim pada akhirnya akan membantu peningkatan efisiensi dan efektivitas pada aktivitas perekonomian yang berkembang di wilayah darat. Sehingga, akan terjadi efek domino yang secara bertahap akan meningkatkan kesejahteraan masyarakat, khususnya masyarakat di wilayah pesisir.

Pengembangan paradigma sangat minim dengan dukungan studi kelayakan kuantitatif memadai, sehingga mampu meyakinkan pengambil kebijakan agar benar-benar berpihak pada rezim pembangunan yang berorientasi pada potensi kelautan dan perikanan. Selama ini, yang berkembang dominan dalam wacana adalah opini dan argumentasi yang dibangun di atas data kasar atau bahkan abstrak. Misalnya adanya potensi kerugian illegal fishing, kemudian dengan mudahnya seolah mengasumsikan seandainya tidak dicuri maka potensi pendapatan negara akan sebesar kerugian yang ditimbulkan illegal fishing. Sebuah asumsi yang sangat menyesatkan, karena kita tidak memiliki akses ke pasarnya, sedangkan pelaku illegal fishing pasti telah memiliki pembeli.

Proyeksi pengembangan perekonomian maritim harus benar-benar dilengkapi perhitungan matematis yang meyakinkan tentang prospek kontribusinya terhadap perekonomian dan kesejahteraan rakyat, sehingga mampu mencuri perhatian pengambil kebijakan. Dengan demikian, dengan sungguh-sungguh memperhatikan potensi perekonomian maritim maka akan tercapai solusi atas upaya percepatan pengentasan kemiskinan dan pencapaian kesejahteraan rakyat.

Pembangunan berorientasi darat sesungguhnya tidak dengan serta merta menjadi prioritas, karena paradigma berpikir yang tertanam dalam benak pengambil kebijakan sebelumnya. Akan tetapi, justru disebabkan faktor yang jauh lebih dominan, yakni adanya fakta tentang aktivitas perekonomian darat yang lebih besar, lebih pesat, dan jauh lebih atraktif dibanding dengan di laut dan fakta tentang kebutuhan kenyamanan masyarakat yang tentu saja tinggal di daratan. Solusi yang paling mendekati peningkatan aktivitas di wilayah laut dan pesisir adalah dengan mengembangkan kota-kota pelabuhan dan obyek-obyek pariwisata atraktif, sebagaimana yang telah ditunjukkan oleh Hongkong dengan memberikan kesempatan seluas-luasnya kepada investor swasta dan pelaku industri properti untuk mengambil peran besar mengembangkan kota pelabuhan dan obyek pariwisata. Tentunya, 
upaya ini tak boleh ditunggangi kepentingan politis dan SARA, sehingga kebijakan mengembangkan kota pelabuhan dan obyek pariwisata benar-benar bertujuan untuk meningkatkan kesejahteraan rakyat,

\section{Urgensi Pembentukan Badan Keamanan Laut (Bakamla)}

Indonesia merupakan negara dengan prospek pertumbuhan ekonomi yang cukup menjanjikan dengan volume perekonomian masuk dalam 16 besar negara di seluruh dunia. Patut disadari bahwa keberlangsungan pembangunan Indonesia di segala bidang sangat tergantung dari sarana prasarana transportasi (perhubungan) dan ketersediaan energi, terutama energi baru dan terbarukan, termasuk hasil eksplorasi sumberdaya energi bawah laut.

Kepentingan suatu negara di wilayah laut, terutama menyangkut masalah pertahanan dan keamanan nasional serta integrasi wilayah secara keseluruhan, yang menjadi modal dasar pelaksanaan tugas pembangunan perekonomian dan upaya peningkatan kesejahteraan rakyat, dapat dilakukan di bawah jaminan rasa aman dan damai.Namun yang tidak kalah penting adalah tugas untuk memastikan terjaminnya keamanan dan keselamatan di wilayah laut.

Konsekuensinya, sebagai negara hukum yang tunduk, terikat, dan patuh pada ketentuan produk hukum dan perundang-undangan berlaku maka menjadi penting untuk menegaskan pengaturan kelautan, termasuk di dalamnya pengaturan ketentuan penyelenggaraan penegakan hukum di wilayah laut, oleh Bakamla, secara jelas dan pengaturan sistem penegakan hukum di laut dimulai penyidikan, penuntutan, dan sistem peradilan yang berwawasan maritim. Cita-cita menjadikan Indonesia sebagai Poros Maritim Dunia harus mampu memastikan bahwa faktor keamanan dan keselamatan di wilayah laut menjadi prioritas utama dalam pengelolaan potensi perekonomian dan potensi-potensi lain sebagai konsekuensi posisi strategis wilayah laut Indonesia di dunia.

Kehadiran Bakamla yang berdaya (powerful) dengan segala kewenangan yang dijamin secara tegas dalam Undang-Undang Kelautan, termasuk memiliki kewenangan penegakan hukum yang didukung unsurcriminal justice system lain berwawasan kemaritiman harus dapat menjamin kepastian hukum.Bakamla bekerja secara efektif dan efisien, menjamin keamanan dan keselamatan laut. Para pengguna jasa transportasi laut serta pelaku ekplorasi dan eksploitasi potensi kekayaan laut pun merasa cukup nyaman, terjamin keamanan dan keselamatannya, serta terbebas dari perompakan dan pungutan liar para preman dan oknum aparat yang mengampu di bidang kelautan. Akhirnya, biaya distribusi di laut yang dirasakan sangat mahal akan dapat ditekan.

UU no. 32 Tahun 2014 ini terdiri dari 13 bab. Ada beberapa implikasi dari lahirnya UU ini. Pertama,lahirnya Badan Keamanan Laut (Bakamla)sebagai implikasi dari Pasal 59. Bakamla merupakan badan penting dalam pengamanan dan penegakan hukum di laut yang berada langsung di bawah presiden. Penjelasan lebih detail terkait Bakamla ada pada Pasal 60,61, dan 62. Kedua,Pasal 30 memiliki implikasi bahwa pemerintah dan pemerintah daerah wajib mengembangkan dan meningkatkan penggunaan angkutan perairan dalam rangka konektivitas antarwilayah, pemerintah harus melaksanakan kebijakan pengembangan armada nasional dalam laut, pemerintah mengatur kebijakan sumber pembiayaan dan perpajakan yang 
berpihak pada kemudahan pengembangan sarana prasarana laut, dan pemerintah memfasilitasi sumber pembiayaan usaha perhubungan laut. Ketiga, pasal 58 memiliki implikasinya dibentuklah sistem pertahanan laut.

\section{Strategi Menangkal Globalisasi Berbasis Maritim}

Menurut Jenderal Abdul Haris Nasution, bahwa yang dimaksud dengan ketahanan nasional itu tidak saja berisi kekuatan militer tetapi menyangkut keadilan, kesejahteraan, dan pemerataan di bidang sosial, ekonomi dan politik. Karena itu strategi ketahanan bangsa harus minimal mencakup pembangunan sosio-ekonomi, sosio-kultural, pertahanan dan keamanan.

Untuk meningkatkan ketahanan Indonesia berbasis maritim, banyak hal harus mendapat perhatian lebih. Terutama guna menghadapi keterbukaan global dan pasar bebas. Tanpa peningkatan ketahanan tersebut, maka posisi geografis menjadi pertaruhan. Agar dapat menangkis ekses pasar bebas dan globalisasi, terdapat strategi yang harus ditempuh. Berikut, strategi sosio-ekonomi, sosio-kultural, pertahanan dan keamanan guna menghadapi globalisasi dan pasar bebas

\section{a. Sosio-Ekonomi}

Harus dilakukan perubahan pembangunan dengan cara mengkombinasikan aktifitas laut dan darat menjadi kesatuan nusantara. Potensi kelautan Indonesia yang selama ini menjadi dasar penguatan struktur ekonomi Indonesia harus dibangun perindustrian yang maju dan modern (terutama di bidang pertanian). Pengembangan ini meliputi pula pertambangan dan energi, migas, pariwisata bagari, jasa kelautan dan bangunan kelautan, pun tidak pula melupakan pembangunan atas sarana transportasi dan sumber daya lautnya. Ekonomi maritime harus menjadi poros pembangunan untuk meningkatkan dan memeratakan kesejahteraan social.

\section{b. Sosio-Kultural}

Agar jatidiri bangsa sebagai bangsa bahari ditemukan kemballi, dibutuhkan adanya revolu budaya. Saat ini nilai-nilai dan budaya maritime Indonesia telah terdegradasi. Untuk meningkatkan dan membangkitkannya, dibutuhkan kepemimpinan oleh masyarakat maritime agraris. Mereka harus menjadi teladan sehingga daoat menjadi penggeraj pilar pembangunan nasional di bidang kemaritiman.

\section{c. Pertahanan dan Keamanan}

Hal yang ahrus diperhatikan sebagai langkah sntisipasi strategis terhadap ekses globalisasi dari perkembangan politik adalah tentang Matitim domain awareness. Naval capability Indonesia harus didasari pada pemfokusan integritas strategis pada area Samudra Pasifik, Samudera Hindia dan Laut CIna. Pembangunan kekuatan harus dilakukan dan ditingkatkan untuk menjamin kemanan dan stabilitas sumber daya maritime Indonesia dan kedaulatan maritime Indonesia. Untuk menghindari tumpeng tinggih kewenangan dibidang kemaritiman, dibutuhkan pula telaah lebih lanjut terhadap epratran perundang-undangan Indonesia yang mengatur mengenai kemaritiman. Strategi berbasis maritime di atas penting dilakukan untuk 
mengurangai dampak negative dan menjaga stabilitas pertahanan dan keamanan nasional kemaritiman Indonesia.

\section{Potensi dan Persebaran Sumber Daya Laut di Indonesia}

Wilayah laut Indonesia yang jauh lebih besar dari daratan yaitu dengan perbandingan 2:1, maka laut Indonesia menyimpan banyak potensi dan sebaran SDL yang teridiri dari SDL hayati dan SDL non hayati. SDL hayati seperti ikan, sedangkan SDL non hayati seperti minyak humi, bauksit, pasir, bijih besi, nikel, timah, dan masih banyak lainnya. Selain SDL dari laut, Indonesia masih memiliki sumber daya alam lainnya di daerah maritim yang disebut sebagai Sumber Daya Pesisir (SDP) seperti terumbu karang, mangrove, dll.

Adapun SDL yang paling banyak dimanpaatkan oleh penduduk dalam hal ini nelayan adalah SDL hayati berupa hasil tangkapan ikan. Potensi penangkapan ikan yang disebut sebagai potensi lestari Indonesia sangatlah besar, yang artinya walaupun terus ditangkap, populasi ikan di laut tidak terancam punah. Potensi lestari ini diatur agar keberlangsungan populasi ikan terus ada. Aturan internasional menetapkan 5,12 juta ton atau sekitar $80 \%$ (delapan puluh persen) jumlah tangkapan ikan maksimal. Faktanya Indonesia masih belum maksimal dalam penangkapan ikan, yang berarti Indonesia masih menyimpan banyak sekali ikan di laut Indonesia.

Sebaran potensi ikan di Indonesia bagian timur dan barat berbeda. Hal ini disebabkan oleha danya perbedaan kedalaman laut. Indoensia bagian barat rata-rata kedalaman lautnya adalah $75 \mathrm{~m}$ sehingga ikan yang dihasikan kebanyakan jenis ikan pelagis kecil. Sedangkan di Indoensia bagian timur dengan lautnya yang sangat dalam mencapat kedalaman 4000m, ikannya jauh lebih beragam dengan bobot yang sangat besar seperti tuna dan cakalang.

Selain memanfaatkan hasil tangkapan ikan, penduduk juga membudi daya ikan. Hal ini kebnyakan dilakukan di pantau utara pulau jawa. Adapun jenis ikan yang dibudidayakan antara lain udang dan banden.

Kondisi geografis Indonesia yang terdiri dari lebih dari 13 ribu pulau meyebabkan banyaknya hutan mangrove di daerah pesisir. Selain hutan mangrove juga terdapat banyak rumput laut, terumbu karang dan pednag lamun. Garis pantai mencapai $81.000 \mathrm{~km}$ menjadikan Indonesia sebagai negara dengan panjang pantai ke-2 terpanjang di dunia sesudah negara Kanada.

Dengan besarnya SDL Indonesia tersebut, sudah benar langkah pemerintah untuk focus pada pembangunan kelautan/maritime Indonesia. Pembangunan tidak hanya tentang infrastruktur tetapi juga pada eprlindungan seperti upaya perlindungan terhadap praktik illegal fishing dimana wilayah Laut Arafuru Papua menjadi wilayah paling rawan praktik illegal fishing di Indonesia.

Tipe hutan yang ebrada di lokasi pasang surutnya laut disebut sebagai hutan bakau atau hutang mangrove. saat surut, hutan mangrove tidak digenangi aiur laut sedangkan saat pasang, air laut menggenangi hutan mangrove. Pantai yang etrlindung dari laguna atau muara pantai adalah tempat berkembnganya hutan mangrove. keberaan hutan mangrove berarti 
tumbuhnya ekosistem di daerahnya sehingga hutan mangrove memiliki fungsi tidak hanya sebagai fungsi ekologis tetapi juga fungsi ekonomis. Fungsi ekologis artinya menjadi habitat bagi makhluk hidup yang mencari makan maupun berlindung serta berkembang biak di hutan mangrove. banyak jenis fauna dan ikan serta udang yang tumbuh disekitar hutan mangrove. selain itu, hutan mangrove dapat melindungi pantai dari abrasi laut. Sedangkan fungsi ekonomis artinya kayu dari pepohonan serta makhluk hidup yang tumbuh dan berkembang biak di hutan mangrove dapat dijadikan sumber penghasilan bagi penduduk.

Indonesia memiliki hutan mangrove yang tersebar di bagian utara pulau jawa, sebelah barat sumatera, sepanjang pesisir Kalimantan, selatan Papua, sepanjang pesisir Sulawesi, dll. Penyebarannya sebenarnya tidak merata. Data dari UNESCO menyebutkan total luas hutan mangrove di Indonesia adalah 3.716.000ha. Adapun luas wilayah hutang mangrove di Sumatera menpaia 417.000ha, Jawa 43.4000ha, di Kalimantan mencapai 165.000ha, Bali dan Nusa Tenggara seluas 3,7ha, Sulawesi 53.000ha, dan terbesar di Papua yang mencapat 3.700.000ha.

Selain hutan mangrove, Indonesia juga kaya akan terumbu karang. Terumbu karang merupakan batu sedimen di laut yang di hasilkan oleh koral yang membentuk koloni-koloni hingga mencpaai ribuan dan terbentuklah kerumbu. Terumbu karang hidup di perairan dengan suhu antara 21 derajat hingga 29 derajat celcius. Indonesia karena merpakan wilayah tropis yang suhunya sangat ideal untuk tumbuhnya terumbu karang menjadikan Indonesia sebagai negara dengan terumbu karang terluas di dunia yang mencapai $284.300 \mathrm{~km} 2$. angka tersebut setara dengan $18 \%$ jumlah terumbu karang seluruh dunia. Apabila suhu laut tidak ideal, maka terumbu karang tidak akan tumbuh dengan baik. Terumbu karang merupakan tempat hidup, berlindung dan berkembang biak berbagai jenis tanaman dan ikan di laut. Setidaknya ada 2500 jenis ikan yang hidup di terumbu karang. Selain itu juga tedapat 2500 jenis moluska, 599 jenis karang dan 1500 jenis udang. Agar dapat tumbuh baik terumbu karang membutuhkan kangdungan tinggi terhadap garam air laut. Karena itu terumbu karang hamper tidak mungkin didapati di daerah air sungai.

Terumbu karang memiliki manfaat ekonomis, ekologis dan social ekonomi yang tinggi. Terumbu karang dapat menjadi sumber obat-obatan, makanan dan objek wisata bahari yang membuat terumbu karang memiliki manfaat ekonomis yang tinggi. Sedangkan manfaat terumbu karang sebagai pengurang dari empasan gelombang yang menjadi penyebab utama abrasi, merupakan manfaat ekologis dari terumbu karang. Terakhir manfaat social ekonomi, karena selain ikan yang dapat dipanen oleh nelayan, terumbu karang yang indah dapat dijadikan sebagai obek wisata yang tentunya dapat meningkatkan pendapatan masyarakat sekitar dan devisa untuk negara.

\section{PENUTUP}

Sumberdaya kelautan memiliki potensi yang besar untuk pengembangan ekonomi nasional dalam rangka mewujudkan poros maritim dunia, namun demikian pengaturan dan pemanfaatannya harus dilaksanakan secara hati-hati agar tidak terjadi kerusakkan 
ekosistemnya seperti yang terjadi pada sumberdaya daratan. Agar hasil laut dapat dimaksimalkan pemanfaatannya, maka Indonesia harus memingkatkan diri dibidang teknologi salah satunya dengan cara membangun kerjasama dengan negara-negara berteknologi maju. Terakhir, agar terwujud cita-cita menjadi poros maritime dunia, Indonesia harus meningkatkan faktor keselamatan dan keamanan wilayah pesisir dan laut. Hal ini dilakukan agar potensi ekonomi dan potensi lainnya dapat di maksimalkan mengingat posisi Indonesia sangat strategis dibidang kemaritiman.

\section{DAFTAR PUSTAKA}

\section{Buku}

Syamsumar Dam, Politik Kelautan, Jakarta: Bumi Aksara, 2010

Departemen Kelautan dan Perikanan Sekretaris Jenderal Satuan Kerja Dewan Maritim Indonesia, Evaluasi Kebijakan Dalam Rangka Implementasi Konevensi Hukum Laut Internasional (UNCLOS 1982) di Indonesia, DKP, Jakarta, 2008;

\section{Internet}

http://www.kemenkeu.go.id/Berita/presiden-indonesia-adalah-poros-maritim-dunia http://jurnalmaritim.com/2016/10/indonesia-poros-maritim-dunia-menuju-ekonomi-berbasiskelautan/

http://bisniskeuangan.kompas.com/read/2016/10/21/203422926/Visi.Maritim.Jokowi.Tantang an.Bernilai.Ribuan.Triliun.Rupiah

http://m.liputan6.com/bisnis/read/2138321/melongok-tol-laut-jokowi-modal-ri-jadi-porosmaritim-dunia

\section{Peraturan Perundang-undangan}

Undang-Undang Dasar Negara Republik Indonesia Tahun 1945.

Undang-Undang Nomor 45 Tahun 2009 tentang Perikanan

Undang-Undang No. 32 tahun 2014 tentang Kelautan.

Undang-Undang No.3 Tahun 2002 tentang Pertahanan Negara

Undang-Undang Nomor 1 Tahun 2014 tentang Pengelolaan Wilayah Pesisir dan Pulau-Pulau Kecil. 